\title{
The use of green fluorescent protein as a marker for Brucella vaccines
}

\author{
Carlos Chacón-Díaza,b, Melissa Muñoz-Rodrígueza ${ }^{a}$, Elías Barquero-Calvo a ${ }^{a}$ Caterina Guzmán-Verri ${ }^{a}$, \\ Esteban Chaves-Olarte ${ }^{\mathrm{a}, \mathrm{b}}$, María Jesús Grilló ${ }^{\mathrm{c}}$, Edgardo Moreno ${ }^{\mathrm{a}, \mathrm{d}, *}$ \\ a Programa de Investigación en Enfermedades Tropicales, Escuela de Medicina Veterinaria, Universidad Nacional, 3000 Heredia, Costa Rica \\ b Centro de Investigación en Enfermedades Tropicales, Facultad de Microbiología, Universidad de Costa Rica, 1000 San José, Costa Rica \\ ${ }^{\mathrm{c}}$ Instituto de Agrobiotecnología, CSIC-UPNA-Gobierno de Navarra, Carretera de Mutilva, s/n. 31192, Mutilva Baja, Navarra, Spain \\ d Instituto Clodomiro Picado, Facultad de Microbiología, Universidad de Costa Rica, San José, Costa Rica
}

\section{A R T I C L E I N F O}

\section{Article history:}

Received 24 April 2010

Received in revised form 4 August 2010

Accepted 26 September 2010

Available online 4 November 2010

\section{Keywords:}

Brucella

Brucellosis

Vaccines

S19

Rev1

GFP

Diagnostic tests

ELISA

\begin{abstract}
A B S T R A C T
Brucellosis is an important malady of productive and wildlife animals and a worldwide zoonosis. The use of effective vaccines and the corresponding diagnostic tests that allow differentiating infected from vaccinated animals are essential tools to control the disease. For this, a prototype of Brucella abortus S19 vaccine expressing green fluorescent protein (S19-GFP) was constructed. The S19-GFP was readily identified under ultraviolet light by macroscopic and microscopic examination and maintained all the biochemical characteristics of the parental S19 vaccine. S19-GFP replicated ex vivo and in vivo, and protected mice against challenge with virulent $B$. abortus to the same extent as the isogenic S19. An immunoenzymatic assay designed to measure anti-GFP antibodies allowed the discrimination between mice vaccinated with S19-GFP and those immunized with S19. Both vaccines raised antibodies against lipopolysaccharide molecule to similar levels. This experimental model constitutes a "proof of concept" for the use of Brucella-GFP vaccines and associated diagnostic tests to distinguish vaccinated from naturally Brucella infected animals.
\end{abstract}

(c) 2010 Elsevier Ltd. All rights reserved.

\section{Introduction}

Brucellosis is a disease of terrestrial and marine mammals and an important zoonosis [1]. Brucella abortus and Brucella melitensis are the most important etiological agents of domestic ruminants. For more than 60 years, the control and eradication programs around the world have used live attenuated B. abortus S19 and B. melitensis Rev1 vaccine strains for protecting large and small domestic ruminants, respectively [1-3]. These vaccines have been used in combination with recurrent diagnosis and removal of the reactive animals [1-4]. In the last decade, however, its use has been restricted based on claims that the serological and bacteriological diagnosis between infected and vaccinated animals is not straightforward [5,6]. Indeed, both B. abortus S19 and B. melitensis Rev1 are smooth attenuated strains capable of generating antibodies against the O-polysaccharide chain of the lipopolysaccharide (LPS) molecule, which is the main bacterial antigen used in the diagnosis of brucellosis [7]. In order to bypass this difficulty, con-

\footnotetext{
* Corresponding author at: Programa de Investigación en Enfermedades Tropicales, Escuela de Medicina Veterinaria, Universidad Nacional, 3000 Heredia, Costa Rica. Tel.: +506 22380761; fax: +506 22381298.

E-mail addresses: emoreno@medvet.una.ac.cr, emoreno@racsa.co.cr (E. Moreno).
}

junctival vaccination route $[2,4,8]$, alternative diagnostic tests $[7,9]$ and mutant vaccines have been used [10,11]. Conjunctival vaccination with $B$. abortus S19 in bovine or B. melitensis Rev1 in caprine and ovine, is an efficient route of immunization inducing lower and less persistent antibodies against LPS. Although these approaches minimize the diagnostic problems of differentiating infected from vaccinated cattle, they do not solve the serological interferences $[12,13]$.

An alternative strategy to avoid the serological interference has been the development of attenuated $B$. abortus and B. melitensis rough vaccines $[11,14,15]$. However, all the O-polysaccharide defective mutants that have been generated are less efficient in protecting animals against virulent infection than the smooth S19 or Rev1 vaccines $[10,16,17]$. After several field trials, the use of rough $B$. abortus RB51 vaccine against bovine brucellosis remains controversial $[10,17,18]$. Moreover, in countries where the disease is endemic and the use of rough RB51 vaccine is compelled, brucellosis remains as an important prevalent disease [10,18-20].

An interesting option has been the development of $B$. abortus S19 and B. melitensis Rev1 deficient in the antigenic periplasmic protein $26 \mathrm{kDa}$ (bp26), and an associated ELISA for the identification of negative vaccinated reactors against this protein [21-27]. However, antibodies against bp26 are only present in a fraction of the infected animals, precluding the straightforward differentiation between vaccinated and field infected cattle [25,28,29]. 
Here, we have explored the use green of fluorescent protein (GFP) as a xenogenic positive marker for the construction of a new prototype of B. abortus S19 vaccine (S19-GFP) and the development of complementary diagnostic assays. We have demonstrated that the S19-GFP displays very similar biological properties as the parental vaccine S19 and allowed the discrimination between mice immunized with S19-GFP and mice infected with 2308 nonfluorescent brucellae.

\section{Materials and methods}

\subsection{Bacterial strains, inocula and growth conditions}

The reference B. abortus S19 and 2308 strains were originally obtained from the culture collection of the Centro de Investigación y Tecnología Agroalimentaria of Aragón, Spain. Handling of strains, growth conditions, and typing of vaccine $B$. abortus S19 and virulent B. abortus 2308 were performed as described elsewhere $[1,3,30]$. Bacterial stability, inoculi, cellular and mice assays were performed as previously described in detail [28].

\subsection{Construction of fluorescent B. abortus strains}

B. abortus S19 and 2308 strains expressing GFP were built as previously reported [31], with some modifications. Briefly, plasmid pBBR-2-gfp derived from pBBR1MCS-2 containing a kanamycin resistance $\left(\mathrm{Km}^{\mathrm{R}}\right)$ cassette and under the control of lac promoter [32], provided by Diego Comerci (Instituto de Investigaciones Biotecnológicas, UNSAM, Argentina), was introduced in competent B. abortus cells by electroporation in a BTX630 (Genetronics, Inc.) apparatus. Successfully transfected brucellae were selected in plates of agar supplemented with $50 \mathrm{mg} / \mathrm{L}$ of kanamycin. For testing in vitro stability of the plasmid insertion, three consecutive subcultures were performed and bacterial counts were determined in agar and agar supplemented with kanamycin. The fluorescent S19-GFP stocks were kept at $-80^{\circ} \mathrm{C}$ in $50 \%$ glycerol, and the stability of phenotypic and molecular characteristics were confirmed in defreeze bacteria stocks. B. abortus 2308 expressing red fluorescent protein (2308-RFP) from Discosoma coral was provided by Dr. Jean-Jacques Letesson (Unité de Recherche en Biologie Moléculaire, Facultés Universitaires Notre-Dame de la Paix, Namur, Belgium).

\subsection{Cell infections}

For intracellular multiplication assays, HeLa cells (ATCC CCL-2) and murine RAW 264.7 macrophages (ATCC TIB-71) were infected with $B$. abortus strains at multiplicity of infection of 500 and 50 bacterial colony forming units (CFU), respectively, following previous protocols $[31,33]$. Adhesion and internalization of $B$. abortus strains in HeLa cells was determined by differential extracellular/intracellular immunofluorescence as described elsewhere $[33,34]$. Bacterial colonies or dispersed Brucella cells were checked for fluorescence under the Chemi Doc XRS apparatus with adequate filter recommended for GFP (Bio-Rad) or by UV microscopy (Olympus $\mathrm{BH}-2$ ), respectively.

\subsection{Mice assays}

Swiss CD1 female 4-6 week-old mice were from the Animal Facility Unit of the University of Costa Rica. Mice were handled, bled and sacrificed according to international recommendations (http://www.felasa.eu/recommendations.htm) and local guidelines of the "Comité Institucional para el Cuidado y Uso de los Animales of the Universidad de Costa Rica", in agreement with the corresponding law "Ley de Bienestar de los Animales No 7451" of Costa Rica.
Residual virulence and protection assays in the mouse models were carried out following standard protocols [3,30,35] with slight modifications. Briefly, for virulence studies, groups of 25 mice were intraperitoneally inoculated with $1 \times 10^{5} \mathrm{CFU} /$ mouse of $B$. abortus strains, and spleen counts determined at different days after infection. For protection studies, three groups of six mice each were injected with $0.1 \mathrm{~mL}$ of PBS for controls, or immunized subcutaneously with $1 \times 10^{5} \mathrm{CFU} /$ mouse of S19 or S19-GFP, respectively. Then, all mice were challenged sixty days later with $5 \times 10^{4} \mathrm{CFU} /$ mouse of the virulent $B$. abortus 2308 by the intraperitoneal route. Two weeks after challenge the number of $B$. abortus 2308 in the spleens of vaccinated mice was determined. In both assays, the data was transformed to logarithms and the mean and standard deviation of CFU/g of spleen was estimated, followed by statistical analysis.

\subsection{Immunochemical assays}

Recombinant GFP was obtained by affinity chromatography as a glutathione-S-transferase (GST-GFP) fusion protein from soluble fraction of $E$. coli XL1-Blue harboring plasmid pGEX-GFP (provided by Matthew Smith, University of California, LA, USA) expression system, and the purity of the fusion protein was determined by SDS-PAGE [36]. Western blotting for estimating the amounts of GFP produced by B. abortus-GFP constructs was performed as described elsewhere [36]. For this monospecific antibodies against GST-GFP were produced by repeated immunizations of mice or sheep as described elsewhere [36]. Reactivity of the obtained antibodies against GFP was tested by agar immunodiffusion [37]. Monoclonal antibody against $B$. abortus Omp19 used for estimating the loading of bacterial lysates was provided by Axel Cloeckaert (INRA, UR1282, Infectiologie Animale et Santé Publique, IASP, Nouzilly F-37380, France).

Indirect enzyme linked immunosorbant assays (ELISA) for the detection of mouse anti-GFP antibodies (ELISA-GFP) was performed on 96 well plates coated with $100 \mu \mathrm{L} /$ well of a $10 \mu \mathrm{g} / \mathrm{mL}$ GFP-GST solution prepared in $0.1 \mathrm{M}$ PBS containing $0.01 \%$ Tween 20 , following standard protocols [38]. Indirect ELISA for the detection of murine anti-Brucella LPS antibodies (ELISA-LPS) was performed as described before [39]. In both ELISAs rabbit anti-mouse IgG ( $\mathrm{H}+\mathrm{L})$ horse radish-peroxidase conjugates (Sigma) were used as detecting reagent, ABTS as substrate, and readings were performed at $405 \mathrm{~nm}$. The immune response against LPS and GFP was evaluated in sera of S19-GFP $(n=25), 2308-G F P(n=25)$ or S19 $(n=25)$ inoculated mice using as negative reference sera of PBS injected control animals $(n=5)$ and bled at different times after infection.

\subsection{Statistical analysis}

In all cases, comparisons of means were performed by one-way ANOVA's test, followed by the Fisher's Protected Least Significant Differences (PLSD) test [30,35].

\section{Results}

\subsection{B. abortus S19-GFP keeps the biological properties of S19 vaccine strain}

B. abortus S19-GFP maintained the growth properties, phenotypic and bacteriological characteristics of the isogenic parental S19 strain, such as smoothness, erythritol and penicillin sensitivity and the distinctive deletion in the ery operon detected by the AMOS-Ery PCR test $[1,30]$. B. abortus-2308-GFP kept its virulent properties as reported elsewhere [31]. Bacterial colonies displayed fluorescence in agar plates grown in the presence or absence of kanamycin and were readily distinguishable from control non-fluorescent Brucella, 


\section{A}

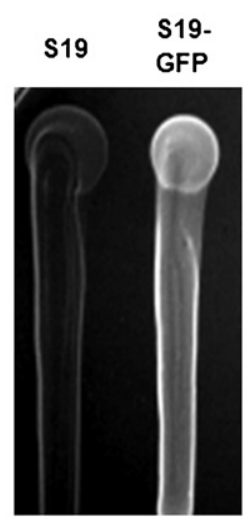

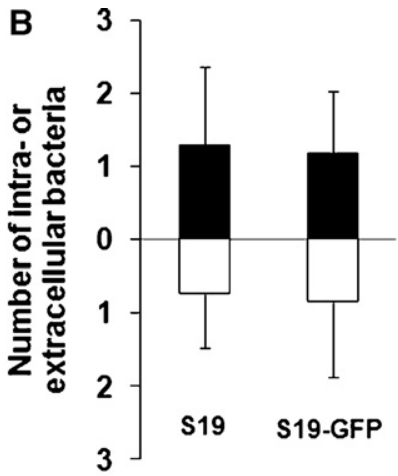

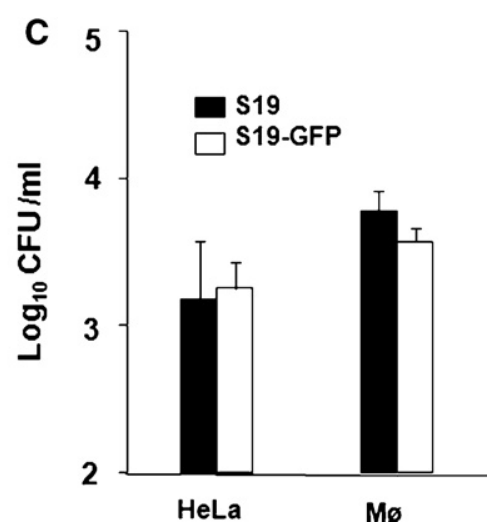

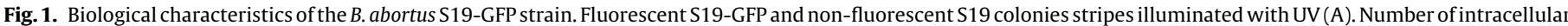

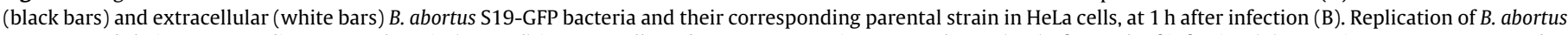

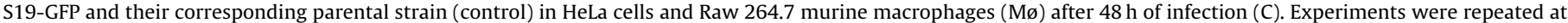
least three times.

Table 1

Proportion of fluorescent B. abortus S19 colonies isolated from spleens of vaccinated mice and HeLa cells. ${ }^{\text {a }}$

\begin{tabular}{|c|c|c|c|}
\hline \multirow[t]{2}{*}{ Experiment } & \multicolumn{2}{|c|}{ Number of S19-GFP isolated from mice } & \multirow{2}{*}{$\begin{array}{l}\text { Number of S19-GFP isolated from HeLa cells } \\
\text { Fluorescent CFU in agar plates } \\
\text { alone/supplemented with kanamycin }^{\mathrm{b}}\end{array}$} \\
\hline & $\begin{array}{l}\text { GFP-CFU in agar plates } \\
\text { alone/supplemented } \\
\text { with kanamycin }\end{array}$ & $\begin{array}{l}\text { GFP-Brucella in } 100 \\
\text { bacteria counted/CFUc }\end{array}$ & \\
\hline A & $100 / 100$ & $96 \pm 3$ & $100 / 100$ \\
\hline $\mathrm{B}$ & $100 / 100$ & $98 \pm 2$ & $100 / 100$ \\
\hline $\mathrm{C}$ & $100 / 100$ & $99 \pm 2$ & $100 / 100$ \\
\hline $\mathrm{D}$ & $100 / 100$ & $97 \pm 4$ & $100 / 100$ \\
\hline
\end{tabular}

a Bacteria were collected from mice after two weeks of infection and from HeLa cells after 2 days of infection.

b CFU of B. abortus S19-GFP where growth in agar plates supplemented or not with $50 \mathrm{mg} / \mathrm{L}$ of kanamycin and then observed under fluorescent light.

c Fluorescent bacteria from five colonies were counted under the ultraviolet light while non-fluorescent bacteria were counted in the same field by phase contrast microscopy.

mainly when grown for four or more days (Fig. 1A). Regardless of the presence or absence of kanamycin in TSA plates, all the S19-GFP CFU from mouse spleens counted displayed fluorescence (Table 1). Microscopic examination of colonies isolated from mice determined that close to $100 \%$ of the counted bacteria were fluorescent (Table 1). The bacteria that did not display fluorescence were presumably dead, because when colonies isolated from mice were subcultured only generated fluorescent CFU. These properties, which remained constant over time, are in agreement with previous observations, demonstrating that plasmids are very stable in $\mathrm{Bru}$ cella cells [40], probably due to the absence of mechanisms to eliminate them since $B$. abortus does not naturally harbor plasmids [1].

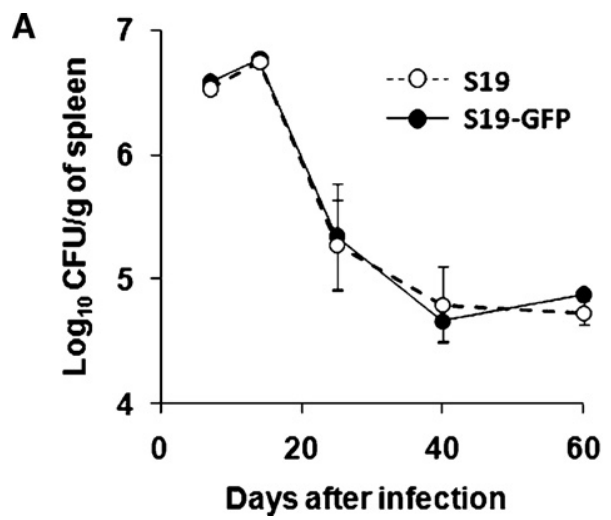

Comparison of S19-GFP with the respective isogenic S19 demonstrated no significant differences in terms of binding to and internalization into HeLa cells, thus maintaining the reported interaction of S19 with host cells (Fig. 1B). Similarly, S19-GFP replicated to the same extent as its parental strain in HeLa cells and in macrophages (Fig. 1C). All CFU recovered from S19-GFP infected macrophages or HeLa cells were fluorescent, demonstrating the stability of the construct (Table 1).

B. abortus S19 follows distinctive replication kinetics in mice, and induces significant levels of protection after challenge with virulent strains [41]. The replication profile of S19-GFP shows a characteristic peak at 14 days of infection paralleling the repli-

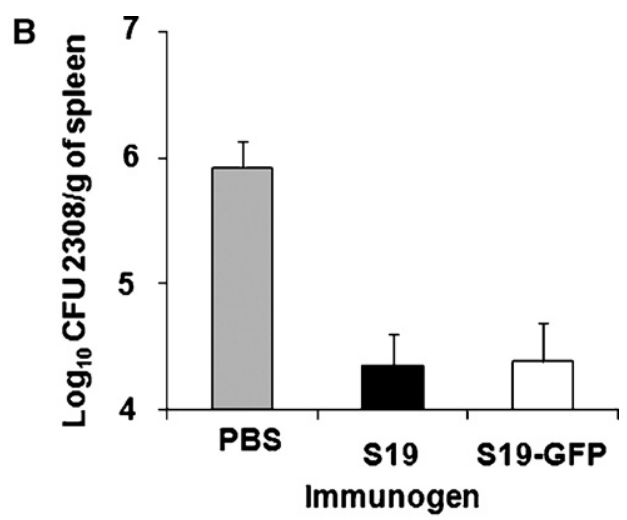

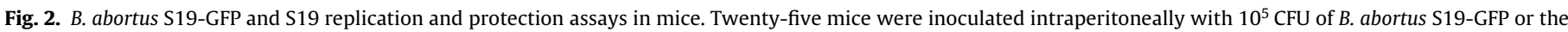

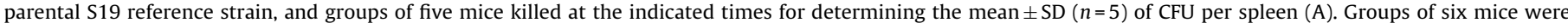

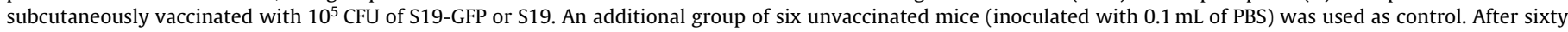

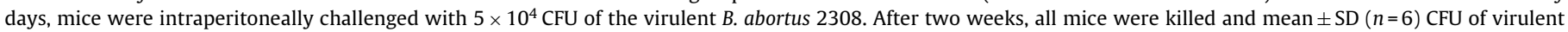
2308 counted in the spleens, after logarithmic transformation (B). Experiments were repeated twice. 

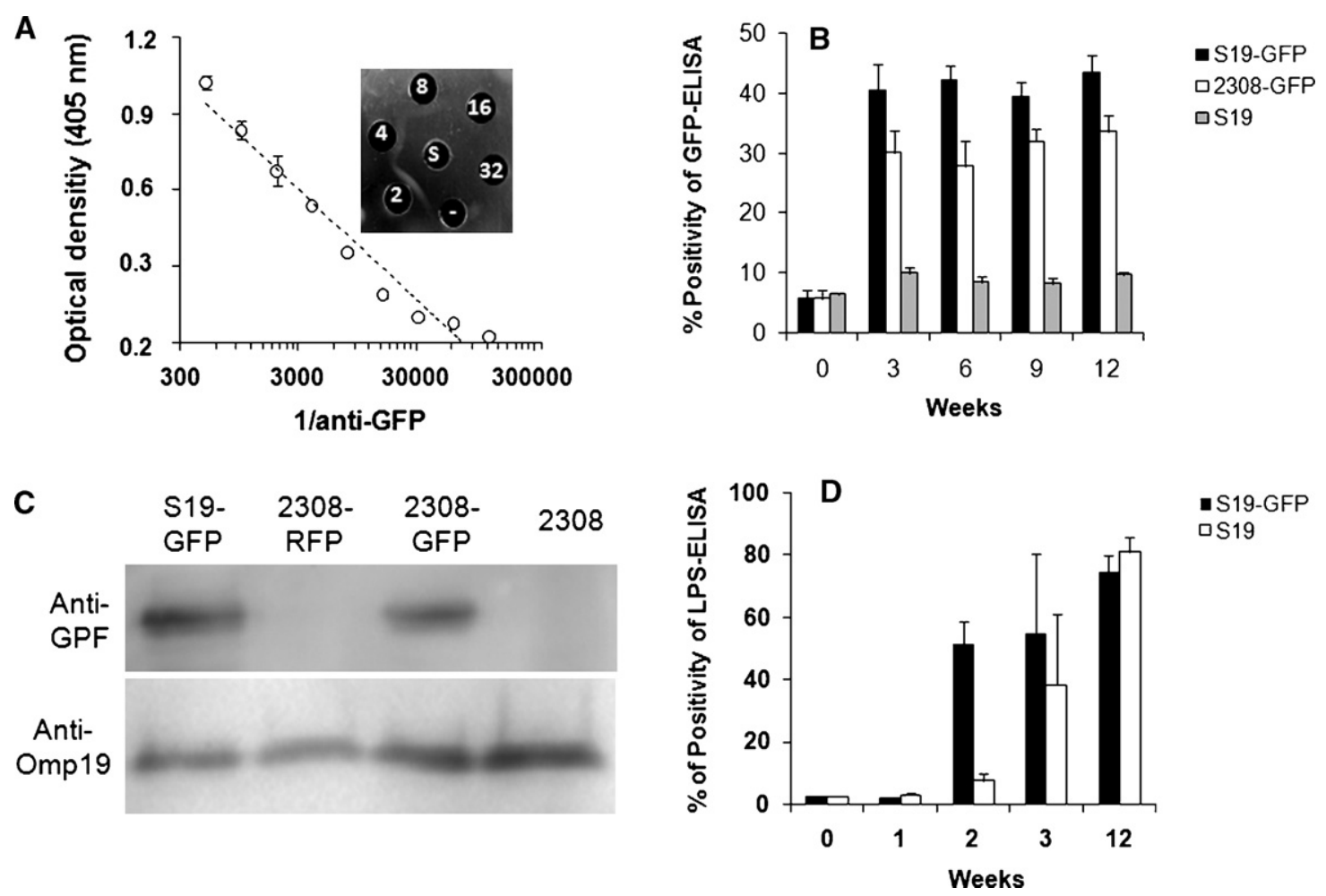

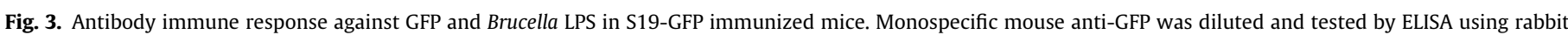

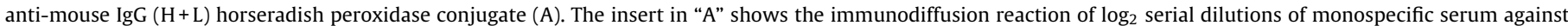

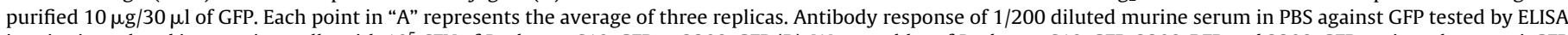

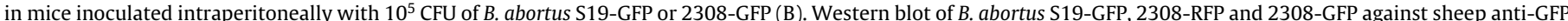

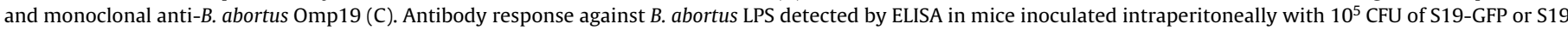
(D). Each point in "B" and " $D$ " represents the average of five mice.

cation profile of the isogenic S19 reference strain (Fig. 2A). In addition, S19-GFP vaccinated mice showed a similar level of protection against challenge with virulent $B$. abortus 2308 than mice vaccinated with S19 (Fig. 2B). In cases in which few colonies of S19GFP were present in challenged animals, they were readily resolved from the $B$. abortus 2308 by fluorescence, without the need of a selective bacteriological agar media.

\subsection{B. abortus S19-GFP induces antibodies against LPS and GFP}

The rational for using a S19-GFP vaccine relies partly on its potential for inducing anti-GFP antibodies in vaccinated animals. This would allow the development of serological tests that could differentiate vaccinated from naturally Brucella infected animals. To test this, an ELISA-GFP for detecting antibodies against GFP in S19-GFP vaccinated animals was developed and tested. Mouse positive control serum against purified GFP demonstrated a single immunoprecipitation band (Fig. 3A) and no reaction against $B$. abortus antigens, including LPS (not shown). This positive control immune serum displayed a proportional ELISA-GFP reaction after dilution, indicating a good correlation between the binding of antibodies to the GFP antigen and the enzymatic reaction (Fig. 3A). All the mice vaccinated with S19-GFP or infected with 2308-GFP produced significant levels $(p<0.001)$ of antibodies against GFP, already detectable at three weeks after inoculation and persistent up to the end of the experiment at 12 weeks after infection (Fig. 3B). All mice injected with S19-GFP showed significantly higher antibody titers $(p<0.001)$ against GFP during the 12 weeks of the assay than mice infected with $B$. abortus 2308-GFP (Fig. 3B). The differences in antibody production between mice vaccinated with S19-GFP and those infected with 2308-GFP, were not due to different expressions of GFP between both strains, as demonstrated by immunodetection of this protein in bacterial lysates (Fig. 3C). Moreover, no cross-reaction against the coral RFP present in 2308RFP lysates was observed with either sheep anti-GFP (Fig. 3C) or mice anti-GFP (not shown), demonstrating the specificity of the reaction. Similarly, none of the mice vaccinated or infected with non-fluorescent isogenic parental B. abortus S19 or 2308 strains developed cross-reacting antibodies against GFP. Although S19GFP vaccinated mice showed variable levels of antibodies against LPS during the first weeks of infection as compared to animals vaccinated with the parental S19 strain, eventually antibodies leveled up at later times (Fig. 3D).

\section{Discussion}

Several attempts to construct Brucella vaccines exhibiting "negative" molecular markers, such as the absence of periplasmic bp26 or O-polysaccharide chain of the LPS, have been reported $[10,11,42,43]$. Although valuable, these approaches have disadvantages. For instance, the value of vaccine candidates devoid of Omps [44] is hampered by the fact that an important proportion of naturally infected individuals do not produce antibodies against this negative cell envelope marker [25,28,29]. Similarly, animals vaccinated with rough $B$. abortus RB51 spontaneous mutant or rough $B$. melitensis punctual mutants, in addition to produce antibodies against many Brucella protein antigens, also generate antibodies against LPS core epitopes and in cases, to residual quantities of $\mathrm{O}$ chain determinants present in some of these rough bacterium, including RB51 $[11,17,45]$. These phenomena may be exacerbated after revaccination; a common practice in many lowincome countries, mainly, when concomitant infections with field Brucella strains are present $[17,18,46]$. In addition, it has been argued that the level of protection of rough mutants is consid- 
erable lower than that conferred by smooth attenuated vaccines $[10,11,18,20]$. Brucella vaccines injected by the subcutaneous route have been shown to produce abortions and they can be isolated from tissues or aborted fetuses $[13,47,48]$, hampering the expedite distinction between field Brucella and vaccine strains. These events complicate the direct and differential bacteriological and serological diagnosis of vaccinated and naturally infected cattle and the further use of vaccines.

Accordingly, all the mice injected with Brucella strains expressing GFP throughout the course of this investigation generated statistically significant levels of specific antibodies against GFP, which were easily detected by the indirect ELISA-GFP developed here. Taking into account that GFP displays a particular structure not related to mammalian proteins or mammal commensal microorganisms [49], it is unlikely that cross-reactions arise, maintaining low background levels. Furthermore, antibodies against GFP raised in sheep and mice do not cross react with related fluorescent proteins such as the coral RFP, which shares critical amino acid motifs and stable three-dimensional beta-can barrel structure with GFP. Although we have observed that the GFP is highly immunogenic in mice and in a restricted number of ovine tested, others have shown that the form in which this fluorescent protein is presented to the immunized animals is relevant for antibody production [50,51]. For instance, while rinderpest virus vaccine expressing membrane-anchored GFP induces good level of antibodies against GFP in cattle, that vaccine designed to produce GFP inside infected cells does not [50,51]. In this regard it is worth noting that vaccinated mice with S19-GFP consistently generated higher levels of antibodies than the 2308-GFP infected animals, despite of the fact that both strains expressed similar quantities of GFP(Fig. 3). Interestingly, B. abortus S19 vaccinated cattle consistently produce lower levels of antibodies against the LPS antigen than infected animals $[2,7,9]$, an event that seems to be reversed in the case of anti-GFP antibodies, at least in the murine model used here. Therefore, the manner in which brucellosis infection proceeds seems to be a relevant factor for the production of antibodies against GFP and LPS.

The S19-GFP vaccine in addition to induce antibodies against the GFP marker antigen, possesses other advantages that eventually could be extrapolated to alternative GFP anti-Brucella vaccines, such as Rev1. First, the S19-GFP is easily distinguished from other Brucella strains by its intrinsic fluorescence, either macroscopically or microscopically, in pure cultures or animal tissues and the presence of the $g f p$ gene in vaccine strains could be detected by a specific PCR. Second, since S19 and Rev1 have been tested extensively over sixty years, and have been shown to be successful vaccines for the control and eradication of ruminant brucellosis [2,4], the need of large and costly trials is precluded. Third, the risk and cost of production should not differ from that of S19 or Rev1 reference vaccines. Fourth, the genetics, biochemical and biological properties of these two Brucella vaccine strains have been extensively studied $[1,11,52]$. Fifth, conventional tests developed to distinguish infected from S19 or Rev1 vaccinated animals will remain functional. This is important because some of these tests are able to distinguish abortions and bacterial shedding due to exacerbated infections with the vaccine strain [47]. And last but not least, it is likely that these vaccines are eagerly accepted by farmers and agriculture authorities, due to the already recognized immunogenic and protective properties of its parent S19 or Rev1 reference strains.

The S19-GFP vaccine studied here is a prototype, containing a non-integrative plasmid that expresses GFP constitutively and owns an antibiotic resistant cassette. In addition it was tested in mice, widely used in experimental brucellosis, but which do not correspond to the natural hosts. In conclusion, our approach constitutes a "proof of concept" demonstrating that brucellae expressing GFP can successfully deliver this protein as an immunogen after infection. The stability, biological behavior and the immunogenic properties of the S19-GFP, makes realistic to design efficient Brucella fluorescent vaccines with a single gfp gene encoded in the chromosome, which then could be used in domestic ruminants and maybe in wild life hosts. Moreover, the S19-GFP tested here provides a standard for comparing the performance of chromosomal GFP-expressing Brucella vaccine candidates in the mouse model, a fact that gives value to this vaccine prototype. The prediction that the high immunogenic properties of the GFP protein would remain in the natural Brucella hosts together with the combination of simple serological tests shall give the appropriate specificity and sensibility to unambiguously differentiate Brucella infected from Brucella-GFP vaccinated animals, is currently being tested in ruminants.

\section{Acknowledgements}

This work was supported by NeTropica, Florida Ice and Farm, FIDA from Universidad Nacional, FS from CONARE, MICIT/CONICIT from Costa Rica and joint Costa Rica-Spain Bilateral Cooperation CRUSA-CSIC (2008CR0006). We are grateful to Ignacio Moriyón and José María Blasco for their comments throughout the experiments performed in this work, and F. Retana and D. Garita for technical assistance. A scholarship to MMR from the German Exchange Service DAAD is also acknowledged.

\section{References}

[1] Moreno E, Moriyón I. The genus Brucella. In: Dworkin M, Falkow S, Rosenberg E, Schleifer K-H, Stackebrant E, editors. The Prokaryotes, vol. 5. New York: Springer-Verlag; 2006. p. 315-456.

[2] Nicoletti P. Vaccination against Brucella. Adv Biotechnol Processes 1990;13:147-68.

[3] Office International des Épizooties. Bovine brucellosis. In: Manual of diagnostic tests and vaccines for terrestrial animals, vol. 2. Paris: OIE; 2009. p. 1-35.

[4] Nicoletti P. Prevention of animal brucellosis: the role of the veterinary services. In: Plommet M, editor. Prevention of brucellosis in Mediterranean countries. Wageningen, Netherlands: International Center for Advanced Mediterranean Agronomic Studies, Pudoc, Scientific Publishers; 1992. p. 113-6.

[5] Elzer PH, Enright FM, Colby L, Hagius SD, Walker JV, Fatemi MB, et al. Protection against infection and abortion induced by virulent challenge exposure after oral vaccination of cattle with Brucella abortus strain RB51. Am J Vet Res 1998;59(12):1575-8.

[6] Schurig GG, Sriranganathan N, Corbel MJ. Brucellosis vaccines: past, present and future. Vet Microbiol 2002;90(1-4):479-96.

[7] Díaz-Aparicio E, Aragón V, Marín C, Alonso B, Font M, Moreno E, et al. Comparative analysis of Brucella serotype A and $\mathrm{M}$ and Yersinia enterocolitica 0:9 polysaccharides for serological diagnosis of brucellosis in cattle, sheep, and goats. J Clin Microbiol 1993;31(12):3136-41.

[8] Plommet M. Progres recents en immunisation contre l'infection a immunisation chez les bovins. Prev Vet Med 1984;2(1-4):205-14.

[9] Gall D, Colling A, Marino O, Moreno E, Nielsen K, Pérez B, et al. Enzyme immunoassays for serological diagnosis of bovine brucellosis: a trial in Latin America. Clin Diagn Lab Immunol 1998;5(5):654-61.

[10] Moriyón I, Grilló MJ, Monreal D, González D, Marín C, López-Goñi I, et al. Rough vaccines in animal brucellosis: structural and genetic basis and present status. Vet Res 2004;35(1):1-38.

[11] González D, Grilló MJ, De Miguel MJ, Ali T, Arce-Gorvel V, Delrue RM, et al. Brucellosis vaccines: assessment of Brucella melitensis lipopolysaccharide rough mutants defective in core and O-polysaccharide synthesis and export. PLoS One 2008;3(7):e2760.

[12] Blasco J. A review of the use of $B$. melitensis Rev 1 vaccine in adult sheep and goats. Prev Vet Med 1997;31(3-4):275-83.

[13] Fensterbank R, Plommet M. Vaccination against bovine brucellosis with a low dose of strain 19 administrated by the conjunctival route IV. Comparison between two methods of vaccination. Ann Res Vet 1979;10(1):131-9.

[14] Winter AJ, Schurig GG, Boyle SM, Sriranganathan N, Bevins JS, Enright FM, et al. Protection of Balb/c mice against homologous and heterologous species of $\mathrm{Bru}$ cella by rough strain vaccines derived from Brucella melitensis and Brucella suis biovar 4. Am J Vet Res 1996;57(5):677-83.

[15] Monreal D, Grilló MJ, González D, Marín CM, De Miguel MJ, López-Goñi I, et al. Characterization of Brucella abortus O-polysaccharide and core lipopolysaccharide mutants and demonstration that a complete core is required for rough vaccines to be efficient against Brucella abortus and Brucella ovis in the mouse model. Infect Immun 2003;71(6):3261-71.

[16] Barrio MB, Grilló MJ, Muñoz PM, Jacques I, González D, De Miguel MJ, et al. Rough mutants defective in core and O-polysaccharide synthesis and export induce antibodies reacting in an indirect ELISA with smooth lipopolysaccharide 
and are less effective than Rev 1 vaccine against Brucella melitensis infection of sheep. Vaccine 2009;27:1741-9.

[17] Blasco JM, Moriyón I. Protection of Brucella abortus RB51 revaccinated cows. Comp Immunol Microbiol Infect Dis 2005;28(5-6):371-3.

[18] Herrera-López E, Suárez-Güemes F, Hernández-Andrade L, Córdova-López D, Díaz-Aparicio E. Epidemiological study of brucellosis in cattle, immunized with Brucella abortus RB51 vaccine in endemic zones. Vaccine 2010 [Epub ahead of print].

[19] Moreno E. Brucellosis in Central America. Vet Microbiol 2002;90(1-4):31-8.

[20] Blasco JM, Moriyón I. Eradication of bovine brucellosis in the Azores Portugal: outcome of a 5-year programme (2002-2007) based on test-and-slaughter and RB51 vaccination. Prev Vet Med 2010;94(1-2):154-7.

[21] Boschiroli ML, Cravero SL, Arese AI, Campos E, Rossetti OL. Protection against infection in mice vaccinated with a Brucella abortus mutant. Infect Immun 1997;65(2):798-800.

[22] Fiorentino MA, Campos E, Cravero S, Arese A, Paolicchi F, Campero C, et al. Protection levels in vaccinated heifers with experimental vaccines Brucella abortus M1-luc and INTA 2. Vet Microbiol 2008;132(3-4):302-11.

[23] Guilloteau LA, Laroucau K, Olivier M, Grilló MJ, Marín CM, Verger JM, et al. Residual virulence and immunogenicity of CGV26 and CGV2631 B. melitensis Rev. 1 deletion mutant strains in sheep after subcutaneous or conjunctival vaccination. Vaccine 2006;24(17):3461-8

[24] Cloeckaert A, Debbarh HSA, Vizcaíno N, Saman E, Dubray G, Zygmunt MS. Cloning, nucleotide sequence, and expression of the Brucella melitensis bp26 gene coding for a protein immunogenic in infected sheep. FEMS Microbiol Lett 1996;140(2-3):139-44.

[25] Debbarh HSA, Zygmunt MS, Dubray G, Cloeckaert A. Competitive Enzymelinked immunosorbent assay using monoclonal antibodies to the $B$. melitensis BP26 protein to evaluate antibody responses in infected and B. melitensis Rev.1 vaccinated sheep. Vet Microbiol 1996;53(3-4):325-37.

[26] Rossetti OL, Arese AI, Boschiroli ML, Cravero SL. Cloning of Brucella abortus gene and characterization of expressed 26-kilodalton periplasmic protein: potential use for diagnosis. J Clin Microbiol 1996;34(1):165-9.

[27] Zygmunt MS, Baucheron S, Vizcaino N, Bowden RA, Cloeckaert A. Single-step purification and evaluation of recombinant BP26 protein for serological diagnosis of Brucella ovis infection in rams. Vet Microbiol 2002;87(3):213-20.

[28] Grilló MJ, Manterola L, de Miguel MJ, Muñoz PM, Blasco JM, Moriyón I, et al. Increases of efficacy as vaccine against Brucella abortus infection in mice by simultaneous inoculation with avirulent smooth bvrS/bvrR and rough wbkA mutants. Vaccine 2006;24(15):2910-6.

[29] Jacques I, Verger JM, Laroucau K, Grayon M, Vizcaino N, Peix A, et al. Immunological responses and protective efficacy against Brucella melitensis induced by bp26 and omp31 B. melitensis Rev 1 deletion mutants in sheep. Vaccine 2007;25(5):794-805.

[30] Mukherjee F, Jain J, Grilló MJ, Blasco JM, Nair M. Evaluation of Brucella abortus S19 vaccine strains by bacteriological tests, molecular analysis of ery loci and virulence in BALB/c mice. Biologicals 2005;33(3):153-60.

[31] Celli J, de Chastellier C, Franchini DM, Pizarro-Cerda J, Moreno E, Gorvel JP. Brucella evades macrophage killing via VirB-dependent sustained interactions with the endoplasmic reticulum. J Exp Med 2003;198(4):545-56.

[32] Kovach ME, Elzer PH, Hill DS, Robertson GT, Farris MA, Roop 2nd RM, et al. Four new derivatives of the broad-host-range cloning vector pBBR1MCS, carrying different antibiotic-resistance cassettes. Gene 1995;166(1):175-6.

[33] Guzmán-Verri C, Chaves-Olarte E, von Eichel-Streiber C, López-Goñi I, Thelestam M, Arvidson S, et al. GTPases of the Rho subfamily are required for Brucella abortus internalization in nonprofessional phagocytes: direct activation of Cdc42. J Biol Chem 2001;276(48):44435-43.
[34] Pizarro-Cerdá J, Moreno E, Sanguedolce V, Mege JL, Gorvel JP. Virulent Brucella abortus prevents lysosome fusion and is distributed within autophagosomelike compartments. Infect Immun 1998;66(5):2387-92.

[35] Grilló MJ, Bosseray N, Blasco JM. In vitro markers and biological activity in mice of seed lot strains and commercial Brucella melitensis Rev 1 and Brucella abortus B19 vaccines. Biologicals 2000;28(2):119-27.

[36] Harlow E, Lane D. Antibodies: a laboratory manual. New York: Cold Spring Harbor, Laboratory; 1988.

[37] Hudson L, Hay FC. Practical immunology. Oxford: Blackwell Scientific; 1976.

[38] Crowther J. Methods in molecular biology. The ELISA guidebook, vol. 149. New Jersey: Human Press Inc; 2001.

[39] Weiss DS, Takeda K, Akira S, Zychlinsky A, Moreno E. MyD88, but not toll-like receptors 4 and 2 , is required for efficient clearance of Brucella abortus. Infect Immun 2005;73(8):5137-43.

[40] Verger JM, Grayon M, Chaslus-Dancla E, Meurisse M, Lafont JP. Conjugative transfer and in vitro/in vivo stability of the broad-host-range IncP R751 plasmid in Brucella spp. Plasmid 1993;29(2):142-6.

[41] Bosseray N, Plommet M. Brucella suis S2, Brucella melitensis Rev. 1 and Brucella abortus S19 living vaccines: residual virulence and immunity induced against three Brucella species challenge strains in mice. Vaccine 1990;8(5):462-8.

[42] Boschiroli L, Cravero S, Arese A, Rossetti OL. Construcción y caracterización de una mutante de Brucella abortus por inactivación de un gen que codifica una proteína de $26 \mathrm{kDa}$. Arch Med Vet 1995;27(SI):103-11.

[43] Cloeckaert A, Jacques I, Grilló MJ, Marín CM, Grayon M, Blasco JM, et al. Development and evaluation as vaccines in mice of Brucella melitensis Rev.1 single and double deletion mutants of the bp26 and omp31 genes coding for antigens of diagnostic significance in ovine brucellosis. Vaccine 2004;22(21-22):2827-35.

[44] Grilló MJ, Marín CM, Barberán M, de Miguel MJ, Laroucau K, Jacques I, et al. Efficacy of bp26 and bp26/omp31 B. melitensis Rev.1 deletion mutants against Brucella ovis in rams. Vaccine 2009;27(2):187-91.

[45] Cloeckaert A, Zygmunt MS, Guilloteau LA. Brucella abortus vaccine strain RB51 produces low levels of M-like O-antigen. Vaccine 2002;20(13-14):1820-2.

[46] Leal-Hernandez M, Díaz-Aparicio E, Pérez R, Andrade LH, Arellano-Reynoso B, Alfonseca E, et al. Protection of Brucella abortus RB51 revaccinated cows, introduced in a herd with active brucellosis, with presence of atypical humoral response. Comp Immunol Microbiol Infect Dis 2005;28(1):63-70.

[47] Nicoletti P. Prevalence and persistence of Brucella abortus strain 19 infections and prevalence of other biotypes in vaccinated adult dairy cattle. J Am Vet Med Assoc 1981;178(2):143-5.

[48] Yazdi HS, Kafi M, Haghkhah M, Tamadon A, Behroozikhah AM, Ghane M. Abortions in pregnant dairy cows after vaccination with Brucella abortus strain RB51. Vet Rec 2009;165(19):570-1.

[49] Prasher DC, Eckenrode VK, Ward WW, Prendergast FG, Cormier MJ. Primary structure of the Aequorea victoria green-fluorescent protein. Gene $1992 ; 111(2): 229-33$.

[50] Walsh EP, Baron MD, Anderson J, Barrett T. Development of a genetically marked recombinant rinderpest vaccine expressing green fluorescent protein. J Gen Virol 2000;81(Pt 3):709-18.

[51] Walsh EP, Baron MD, Rennie LF, Monaghan P, Anderson J, Barrett T. Recombinant rinderpest vaccines expressing membrane-anchored proteins as genetic markers: evidence of exclusion of marker protein from the virus envelope. J Virol 2000;74(21):10165-75.

[52] Crasta OR, Folkerts O, Fei Z, Mane SP, Evans C, Martino-Catt S, et al. Genome sequence of Brucella abortus vaccine strain S19 compared to virulent strains yields candidate virulence genes. PLoS One 2008;3(5):e2193. 